\title{
AREAS OF EXPERTISE, TYPES OF SERVICES GIVEN AND CLIENT INDUSTRIES OF DESIGN CONSULTANCY FIRMS IN TURKEY
}

\author{
Müzeyyen ALPARSLAN, Naz A.G.Z. BÖREKÇİ
}

Received: 15.10.2010; Final Text: 12.05.2011

Keywords: industrial design; design consultancy; Turkish industry.

\section{INTRODUCTION}

This article presents part of a survey carried out to determine the scope of design consultancy in Turkey. The survey was conducted as part of a master's thesis carried out in the graduate program at METU Department of Industrial Design. The article explores the role of design consultancy in Turkey in fulfilling product development needs of client firms, who may be firms from the industry, as well as clients who are not manufacturers.

Design consultancy in Turkey is a small business run since the 1980s. Current design consultancies are dispersed and the services given are so far unidentified. The article begins with a brief discussion on industrial design in Turkey to provide a background for the survey findings. The methodology of the survey is explained; the findings are presented. Based on the findings, the article states types of services that design consultancies offer to client firms, and identifies how design consultancy requirements of client firms change according to size. The article then discusses industries that use design consultancies in high and low frequencies, in order to understand how the various dynamics may be affecting decisions for seeking design consultancy services. Finally the article suggests motivations for and reservations against using design consultancy of client firms, for their product development activities.

\section{BACKGROUND ON INDUSTRIAL DESIGN IN TURKEY}

Industry in Turkey took long to recognize the need for professional design services. The government followed an import substitute policy until mid-1980s to support the development of industrialisation, and to strengthen and protect national markets against foreign competition. Although the 60s and 70s saw a rapid development, industry was not encouraged to invest in technology and product development activities, as would be expected (Er, 1993). A limited number of industries that carried 
out product development activities, as well as universities planning for industrial design education, played a significant role in the promotion of the profession.

\section{0s}

Industrial design education in Turkey began in the 70s. In the 80s, a number of professionals beginning their career found employment in manufacturing firms while some chose to pursue an academic career. Those who established their own design consultancy firms had to pursue consultancy in fields other than industrial design, such as interior architecture, graphic design and computer drafting in order to keep business running. The earlier attempts to establish a professional society led to the establishment of Industrial Designers Society of Turkey (ETMK) in 1988. The aim was to promote industrial design to the public and the industry, and to establish and protect the rights of practising industrial designers.

\section{0s}

Interest of the industry towards industrial design rose, as manufacturers recognized the need to develop original products to compete for export particularly with the adoption of liberal economic policies in the 1980s and the establishment of customs union between Turkey and EU countries in the 1990s. Government support was provided for the development of SMEs and their research and development activities (SPO, 1989). Graduates of industrial design found more employment opportunities in the industry. Besides, industry began to show more interest in industrial design education (Korkut and Hasdoğan, 1998). A major setback was that, firms invested in their manufacturing facilities, and not particularly on developing own brands. Some established industries chose to join transnational companies, manufacturing under licence agreements, which led to the disappearance of some Turkish brands (Er, 2002). Therefore, although there was a rapid growth in industry, Turkish brands and Turkish design did not prosper.

In the same decade, the decree law for the protection of intellectual property rights was developed with support from government related institutions. Opinion of design professionals was sought for, and ETMK was represented in the meetings. The decree law has been in practice since 1995, encouraging design protection in Turkish industry. The decade also saw a rise in the number of publications on various fields of design though none specific to product design. Today, product design is regularly covered in industry and business related national publications on topics such as marketing, architecture and automotive.

Er and Korkut (1998) provide a chronological account of the developments in industrial design education, research and practice in Turkey. In 1994 the first national design exhibition "Designers' Odyssey" was organized by ETMK in Ankara where awards were distributed and a catalogue of the exhibited products was published. In 1995 products of Turkish designers were exhibited internationally for the first time by ETMK with a slide show in Taiwan TIDEX '95 design fair, held within the ICSID conference.

\section{0s}

Although there is still not a national design policy in Turkey, industrial design has become a popular issue particularly in this last decade. News related to design find more press coverage. There are numerous national 
design portals and related websites open to the industry and the public. Design exhibitions, regular design fairs and business conventions are held, promoting industrial design and bringing together professionals and the industry. Seminars and panels on industrial design held within these events aim to inform the audience. Industrial fairs volunteer to host exhibitions for student projects, also promoting education. Industrial firms give importance to regular participation in international design fairs. Professionals occasionally come together to organise participation to international design exhibitions.

There is rise in the number of design competitions organised by industrial firms and professional organizations. Competitions particularly target design students, with the aim of introducing industry to who will be their prospective employees, the future professionals and setting forth the strengths and needs of the industry. Design professionals and manufacturing firms apply for national and international awards. Awards won, significantly contribute to marketing activities. In 2008 Design Turkey Awards were issued for the first time, and in 2010 for the second time, to be repeated every two years.

The ongoing European Union adaptation process has brought recognition to the profession, particularly in the eyes of the industry, the government and educational institutions. Discussions on professional recognition led to the forming of Industrial Designers Academic Council (ETAK) a platform for heads of industrial design education departments. With the initiation of the Turkish Patent Institute, Turkish Design Advisory Council held its first meeting in October 2009. The Council is making attempts to prepare a national design policy.

The rising interest in the profession has led to the opening of industrial design departments. At the date this paper is written into its final version (May 2011), there are 19 active undergraduate programs in Turkish universities, fourteen begun after 2000. Universities encourage research for industry through collaboration, such as industry supported theses. There is also visible support from the industry for industrial design education (Evyapan et al., 2006). The increased number of industrial design departments leads to the increased number of graduates, the majority of whom find employment in the industry. At the onset of this new decade, there is increase in the number of professionals establishing their own design consultancy firms.

\section{FINDINGS OF THE SURVEY}

\section{Aim}

Considering the rise in interest in industrial design from industry and public, and the government support for the use of design as an added value in products with export potential, a survey was conducted in 2006 to identify the types of services offered by design consultancy firms in Turkey. This survey was part of a master's thesis, conducted in the Master of Science in Industrial Design Program at METU Department of Industrial Design (1).

1. Müzeyyen Sözen (Alparslan) (2007) Design Consultancy in Turkey: A Study on the Business Structure, Services and Clients, Unpublished MS Thesis, METU Department of Industrial Design, February 2007, Supervisor: Asst. Prof. Dr. Naz A.G.Z. Börekçi.

\section{Methodology}

The survey questionnaire consisted of 20 items, inquiring firm size and structure, history, number and background of staff, major projects carried out, business experience and future prospects. The focus of this paper is 
on the answers given to the set of five questions inquiring the areas of expertise of the firms, the industries to which firms give design consultancy services, the types of services given, size of the client firms and whether the types of services differ according to the size of client firms. The first four questions were multiple choice questions evaluated by Likert Scale consisting of five degrees (Never 1; Rarely 2; Sometimes 3; Many times 4; Frequently 5). The fifth question involved a table to be filled.

\section{Survey Sample}

The firms to take part in the survey were identified through ETMK database and various digital design portals, based on the information of whether an industrial designer was working in or running the firm, and also on whether design was cited among the services offered by a firm advertising on the Web. It turned out that those firms were mainly located in the three major cities, where 10 of 11 departments with an undergraduate program in industrial design were located in 2006. The reasons why design consultancy firms are not identified in the other cities with developing industry may be that:

- Industrial design services are not required in these industries as product development may be carried out within research and development (R\&D) activities;

- Industrial designers are employed as in-house designers and firms do not require external design services;

- These industries may be the manufacturing facilities of firms conducting design development activities in headquarters located in other cities.

Response from 20 to 25 firms was expected, as design consultancy in the field of industrial design had a limited capacity as of 2006. Nevertheless, the questionnaire was sent to sixty firms, with the expectation of identifying multi-professional design consultancy firms that give also industrial design services. Twenty firms responded.

\section{Location of the Firms}

The distribution of the respondents according to cities is as follows:

- Fourteen firms are from İstanbul, a centre of business in the leading industrial region Marmara.

- Three firms are from Ankara, the capital and the centre of bureaucracy and finance. Furniture industry, which distributes to the region and exports to neighbouring countries, and various manufacturing and R\&D firms for defence industry are here located.

- Three firms are from İzmir, the port city by the Aegean sea, and located in a major region for agriculture, commerce and industry.

\section{Background of the Firms and Profession of the Employees}

Eight out of 20 firms are established immediately following graduation: Seven respondents indicated that they are owners or founding partners of firms established following graduation. One firm is established by an owner, partner to a previously owned firm, also established following graduation and so considered established upon graduation. Two of these firms indicated that the partners have been providing external design services while still students. 
Seven out of 20 firms are established following consultancy experience: Six firms are established by partners or owners who previously worked in design consultancy firms. One firm is established by a designer who worked in design education and did part-time design consultancy in the past, which puts the firm also in the category of being established by an owner with consultancy experience.

Five out of 20 firms are with industry experience: Four firms are established by designers who had worked for the industry. One firm has been in business since the early 70s; specializing in a certain type of product, and has its own manufacturing facilities and showroom, therefore is considered to have industry experience.

Six out of 20 firms indicated that their employees working on product development are industrial designers. One firm indicated to having no industrial designer employee while another did not indicate the background of the employees. The professions of the employees are as follows: industrial designer (43), architect (6), interior architect (4), graphic designer (3), mechanical engineer (3), electronics engineer (3), design engineer (1), mechanical designer (1), ceramics and glass designer (1), patent agent with MS in mechanical engineering (1).

Five firms seek external services from time to time. Two of these omitted to mention the nature of external services sought; one indicated that they use external computer modelling and rendering services. The fourth firm indicated that they work with external marketing, manufacturing and project management experts. The fifth firm, with multi-professional employees, indicated that they use external services of industrial designers.

The mean value for the number of employees including office staff is 5,4. Firms in business for a longer time, have a higher number of employees in general, and a higher number of employees from disciplines other than industrial design.

\section{Main Areas of Expertise of the Firms}

One question inquired the areas of expertise of the design consultancy firms and their level of expertise on a Likert scale (Table 1). The results indicate that 'product design', followed by 'interior architecture', are the main areas of expertise. The other areas besides those given in the table are, 'conceptual design'; 'creating design-focused projects'; ' project identification'; 'forming networks between companies, producers and designers'; ' 'research'; ' 'experimental projects'; 'strategic design consultancy on product development'; ' animation'; ' production and project application' and 'design of product and exhibition displays'.

\begin{tabular}{|l|c|}
\hline What are the areas of expertise of your firm? & Average \\
\hline Product Design & 3,85 \\
\hline Interior Architecture, Decoration & 3,60 \\
\hline Advertising and Exhibition Stand Design & 2,80 \\
\hline Packaging Design & 2,55 \\
\hline Brand Creation & 2,55 \\
\hline Marketing & 2,25 \\
\hline Rapid Prototyping & 2,00 \\
\hline Other & 1,85 \\
\hline Web Design & 1,50 \\
\hline Multimedia Design & 1,20 \\
\hline
\end{tabular}




\begin{tabular}{|l|c|}
\hline $\begin{array}{l}\text { Until now, which industries in Turkey } \\
\text { have you served as a design consultancy } \\
\text { firm? }\end{array}$ & Average \\
\hline Furniture & 3,20 \\
\hline Exhibition stands and display & 3,15 \\
\hline Promotion products & 2,55 \\
\hline Electronics & 2,30 \\
\hline Packaging & 2,30 \\
\hline Electric home appliances & 2,05 \\
\hline Lighting & 2,05 \\
\hline Communication & 1,90 \\
\hline White goods & 1,80 \\
\hline Automotive & 1,80 \\
\hline Kitchen utensils and table ware & 1,70 \\
\hline
\end{tabular}

\begin{tabular}{|l|c|}
\hline $\begin{array}{l}\text { Until now, which industries in Turkey have } \\
\text { you served as a design consultancy firm? }\end{array}$ & Average \\
\hline Glass & 1,65 \\
\hline Jewellery & 1,65 \\
\hline Other & 1,65 \\
\hline Ceramics sanitary ware & 1,60 \\
\hline Food products & 1,50 \\
\hline Fashion and accessories & 1,45 \\
\hline Medical equipment & 1,40 \\
\hline Industrial machines & 1,35 \\
\hline Defence industry & 1,25 \\
\hline Tourism & 1,25 \\
\hline Toy & 1,10 \\
\hline
\end{tabular}

Table 2. Client Industries and Frequency of Service (Over 5).

Table 3. Types of Services Given and their Frequency (Over 5).

\section{Industries that Take Design Consultancy Services}

The following question inquired the client industries of design consultancy firms and the frequency of their application for consultancy on a Likert scale (Table 2). The results indicate that firms have mostly served 'furniture industry' and 'exhibition stands and displays' sector. Large scale manufacturers from strong industries carrying out product development activities, namely, 'white goods', 'automotiv' and 'ceramics sanitary ware', seem to require design consultancy in a low frequency.

\section{Types of Design Consultancy Services Given}

The following question inquired the types and frequency of services that design consultancy firms provide, on a Likert scale (Table 3). The results indicate that design consultancy firms mostly give services in 'product design', 'concept development' and 'project drawing', in that order, in frequency. Other types of consultancy service mentioned by a firm apart from those given on the table are 'strategic design' and 'trend consultancy'.

\begin{tabular}{|l|c|}
\hline $\begin{array}{l}\text { What are the design consultancy } \\
\text { services that your firm offers? }\end{array}$ & Average \\
\hline Product design & 4,30 \\
\hline Concept development & 4,25 \\
\hline Project drawing & 4,00 \\
\hline Production follow-up & 3,55 \\
\hline Product analysis & 3,50 \\
\hline Project management & 3,30 \\
\hline Brief preparation and detailing & 3,20 \\
\hline Prototyping & 3,05 \\
\hline Ergonomic analysis & 2,85 \\
\hline Project application & 2,85 \\
\hline Technical research & 2,75 \\
\hline Brand and selling strategy & 2,65 \\
\hline Preparing for production and pilot production & 2,65 \\
\hline Assembly & 2,65 \\
\hline Promotion and design of advertisement materials & 2,65 \\
\hline Market research & 2,60 \\
\hline
\end{tabular}

\begin{tabular}{|l|c|}
\hline $\begin{array}{l}\text { What are the design consultancy } \\
\text { services that your firm offers? }\end{array}$ & Average \\
\hline Cost analysis & 2,55 \\
\hline Competition analysis & 2,50 \\
\hline Production & 2,50 \\
\hline Interface design & 2,40 \\
\hline Quality Control & 2,40 \\
\hline Technical support & 2,20 \\
\hline Shipping/transportation & 2,15 \\
\hline Investment analysis & 2,10 \\
\hline Field tests & 2,10 \\
\hline Cost accounting & 1,95 \\
\hline Storage & 1,95 \\
\hline Engineering & 1,90 \\
\hline Assessment of customer satisfaction & 1,90 \\
\hline Seminar or workshop organization & 1,75 \\
\hline Logistic support & 1,65 \\
\hline Other & 0,50 \\
\hline
\end{tabular}


Table 4. Size of Client Firms and Frequency of Service (Over 5).
Table 5. Differences in Types of Services Given to Small and Medium Size and Large Scale Client Firms.

\section{Size of Client Firms}

The following question inquired the size of the client firms who require design consultancy services and the frequency in which consultancy firms give services to different size firms on a Likert scale (Table 4). Results indicate that design consultancy firms serve small and medium size client firms in a slightly higher frequency than large scale client firms.

\begin{tabular}{|l|c|}
\hline $\begin{array}{l}\text { Indicate the size of the client firms } \\
\text { to whom you give service as a design } \\
\text { consultancy firm. }\end{array}$ & Average \\
\hline Small and medium size firms & 2,35 \\
\hline Large scale firms & 2,10 \\
\hline
\end{tabular}

\section{Differences in Design Consultancy Services according to Size of Client Firms}

The final question inquired the differences of types of design consultancy services according to the size of client firms (Table 5). The respondents crossed on a table, where the first column listed types of services and the top row marked the size of the client firms, the relevant box to indicate whether they give the particular service to small and medium size firms or to large scale firms. In some cases, both boxes could be crossed if the firm thought they gave a type of service to client firms from both sizes in equal amount. Three firms did not answer this question, and the answers of one firm were invalid.

The services mostly given to small and medium size client firms are: 'project management', 'product design', 'project drawing', 'product identification and analysis', 'concept development', 'ergonomic analysis' and 'prototyping'. The services mostly given to large scale client firms are:

\begin{tabular}{|l|c|c|}
\hline $\begin{array}{l}\text { How do the design } \\
\text { consultancy services that } \\
\text { you give differ according } \\
\text { to the size of your client } \\
\text { firms? }\end{array}$ & $\begin{array}{c}\text { S\&M Size } \\
\text { Client } \\
\text { Firms } \\
\text { TOTAL }\end{array}$ & $\begin{array}{c}\text { Large } \\
\text { Scale } \\
\text { Client } \\
\text { Firms } \\
\text { TOTAL }\end{array}$ \\
\hline Project Management & $\mathbf{1 4}$ & 3 \\
\hline Product design & $\mathbf{1 3}$ & 8 \\
\hline Project drawing & $\mathbf{1 2}$ & 9 \\
\hline $\begin{array}{l}\text { Product identification and } \\
\text { analysis }\end{array}$ & $\mathbf{9}$ & 7 \\
\hline Concept development & 8 & $\mathbf{1 1}$ \\
\hline Ergonomic analysis & 8 & 8 \\
\hline Prototyping & $\mathbf{8}$ & 6 \\
\hline Market research & $\mathbf{7}$ & 3 \\
\hline $\begin{array}{l}\text { Branding and sales strategy } \\
\text { development }\end{array}$ & $\mathbf{7}$ & 2 \\
\hline Project application & $\mathbf{7}$ & 6 \\
\hline Production follow-up & $\mathbf{7}$ & 6 \\
\hline Competition analysis & $\mathbf{6}$ & 5 \\
\hline Technical research & 6 & 6 \\
\hline Technical support & $\mathbf{5}$ & 3 \\
\hline
\end{tabular}

\begin{tabular}{|l|c|c|}
\hline $\begin{array}{l}\text { How do the design } \\
\text { consultancy services that you } \\
\text { give differ according to the } \\
\text { size of your client firms? }\end{array}$ & $\begin{array}{c}\text { S\&M Size } \\
\text { Client } \\
\text { Firms } \\
\text { TOTAL }\end{array}$ & $\begin{array}{c}\text { Large } \\
\text { Scale } \\
\text { Client } \\
\text { Firms } \\
\text { TOTAL }\end{array}$ \\
\hline Brief preparation & $\mathbf{5}$ & 3 \\
\hline $\begin{array}{l}\text { Preparation for production/ } \\
\text { pilot production }\end{array}$ & 4 & 4 \\
\hline Assembly & 4 & 4 \\
\hline Quality control & $\mathbf{4}$ & 3 \\
\hline Investment analysis & 3 & 3 \\
\hline Engineering & 3 & 3 \\
\hline Seminars and workshops & 3 & 3 \\
\hline Interface design & 2 & $\mathbf{7}$ \\
\hline Cost accounting & $\mathbf{2}$ & 1 \\
\hline Storage & 2 & $\mathbf{4}$ \\
\hline Shipping/transportation & 2 & $\mathbf{4}$ \\
\hline Field tests & 1 & $\mathbf{3}$ \\
\hline Logistic support & 0 & $\mathbf{1}$ \\
\hline Other & 0 & 0 \\
\hline
\end{tabular}


'concept development', 'project drawing', 'product design', 'ergonomic analysis', 'product identification and analysis,' and 'interface design'.

The implications of the survey findings are discussed in the following sections of this article.

\section{DESIGN CONSULTANCY REQUIREMENTS OF CLIENT FIRMS}

Though requiring further research on manufacturing firms and their product development strategies, the results of the survey suggest that manufacturers that mostly apply for design consultancy services are:

- small and medium size enterprises with no in-house product development activities but having their own brand and product range;

- medium size and large scale enterprises with R\&D departments but with no in-house designers for product development; and

- large scale enterprises with in-house product development capabilities but still requiring fresh ideas from time to time.

According to the survey results, design consultancy in Turkey is product development and production oriented, and the services sought are determined by the production capabilities and target markets of the particular client firm. Client firms are mostly manufacturers who commission design consultancies with the expectation of the development of a product suitable to their production line or of novel product concepts for future use. Clients who are not manufacturers may also take design consultancy services. Industrial design professionals are sought for in those sectors, which may actually require expertise from other fields of design, such as graphics or interior architecture.

\section{Design Consultancy Requirements of Small and Medium Size Manufacturers}

Survey results indicate that small and medium size client firms mostly apply for services of project management, product design and project drawing. Results indicate also that such firms apply for marketing related services far more than large scale manufacturers do. Small and medium size manufacturers in Turkey generally do not have in-house designers; also they may have limited human and technical resources for product development, project management and marketing. Particularly those firms with their own brands competing in the market may apply more often for consultancy services for their product development and marketing activities.

\section{Design Consultancy Requirements of Large Scale Manufacturers}

Survey results indicate that large scale client firms require mostly concept development from design consultancies. Large scale manufacturers with in-house industrial designers from time to time want to take design consultancy services for novel product concepts, which they may not immediately turn into products but may keep for future use. Or else, they may use their in-house designers to adapt these concepts to the production line of the firm, utilising their own human resources and technical knowhow. 


\section{DIFFERENCES IN THE DESIGN CONSULTANCY REQUIREMENTS OF MAJOR INDUSTRIES IN TURKEY}

The survey reveals that there are differences in design consultancy requirements of client firms from different industrial sectors. Industries that are particularly strong and rooted for decades, require design consultancy services, even though they have in-house designers and carry out in-house product development activities. On the other hand, conservative industries with product development activities, require design consultancy services in a low frequency.

The survey also reveals that, although the project in hand may require different expertise, design consultancy services are required particularly from industrial design professionals. Interior architecture comes second in frequency as an area of expertise. This is significant, considering that clients for such projects are not manufacturers but may be individuals commissioning designers for one-time projects, as well as corporations which need refurbishment of offices. In this case, designers tend to work with contractors for the production and follow through the application of the projects.

- Firms who claim expertise in this area are either with a multiprofessional composition of employees, particularly architects and interior designers, or

- $\quad$ have carried out interior design projects since early career. In the 80 s, while industry was still not acquainted with the services of industrial design, design consultancies have had to carry out interior design projects to keep their business running. This seems to have contributed to the experience building of the firms and continues as a tradition.

\section{Industries that Require Design Consultancy in a High Frequency}

\section{a. Furniture Industry}

Survey results indicate that consultancy firms have mostly served furniture industry. The well established furniture industry in Turkey is composed of small and medium size and large scale enterprises. This industry may be better understood if office furniture and home furniture are discussed separately. Office furniture is a major industry, and is led by large scale and medium size companies. Some companies export under their brand names and some have international dealers. As office furniture is suitable for mass production, this industry is quite accustomed to the services of industrial design and is among the leading industries in Turkey employing in-house designers.

- Besides in-house designers, large scale manufacturers also tend to take design consultancy services of local and international designers, and Turkish designers who are in the international design arena.

Alongside large scale manufacturers with mass production capabilities and in-house designers, home furniture has quite a number of small and medium size manufacturing companies of a workshop-based production typology. Products are generally inspired by the market and design services omitted, as they will raise the cost of manufacturing and therefore the price of the product. 
- Nevertheless, there are manufacturers that take design consultancy services for product development and design in particular, depending on how high their targeted market segment is.

- Due to the manufacturing process of home furniture industry, where developing products with one-to-one scale prototypes is not so expensive, design consultancy firms occasionally make furniture design and have them produced to be exhibited in industrial fairs and design exhibitions to promote business and sell their designs. This strategy may be a reason why firms, particularly those in business for a shorter time, serve the furniture industry more.

\section{b. Exhibition Stands}

Survey results indicate that exhibition stands and displays sector follows furniture industry in receiving design consultancy services. Frequent trade fairs and business conventions boost up this sector.

- Exhibition and fair stands do not need mass production; they can be dismantled and reconstructed to be reused. Designers can follow the production and construction of these stands in person.

- In the 80s when professionals first started in business, fair stand design was a major area from where firms found clients. This past experience may be a reason why firms that have been in business longer, serve this industry more.

- The employment of interior architects and architects in the firms may be facilitating the design and construction of exhibition projects.

\section{Industries that Require Design Consultancy in a Low Frequency}

\section{a. White Goods, Electrical Home Appliances and Electronics}

Survey results indicate that, white goods industry requires design consultancy services in a low frequency. White goods is a major industry, and the number of manufacturers is few. Some major manufacturers also have in their product range, electronics and electrical home appliances. Besides own brands for local and international markets, companies may be suppliers for international brands; they may have manufacturing alliances abroad for some of their product ranges. Export of white goods and electronics is high. With strategy development and branding activities requiring intense marketing, $R \& D$ and product development activities, this industry is among the leading to have in-house design departments collaborating with R\&D and marketing departments.

Recently, some medium size local manufacturer firms have passed on to international companies, becoming brand suppliers for local and regional markets. Industrial facilities may be used for the manufacture of product ranges marketed internationally. Their main product development and $\mathrm{R} \& \mathrm{D}$ activities are carried out abroad, while in-house designers determine the local and regional branding strategies and work on localising the products.

Also recently, medium size supplier companies are commissioning design consultancies for developing product ranges. There are marketing companies that commission designers to develop products and have them manufactured abroad. 
- It can be said that large scale manufacturers tend to keep product development activities in-house, whereas a limited number of small and medium size manufacturers and marketing companies may occasionally use design consultancy services for developing their product range. This may be the reason why this industry has a low frequency of working with design consultancies.

\section{b. Automotive}

Survey results indicate that the automotive industry requires design consultancy services in a low frequency. There are manufacturing plants of international brands with local alliances for automobiles. In these companies, the main R\&D and design activities are carried out in headquarters located abroad. In the Turkey branches, R\&D activities are carried out for production, and in-house industrial designers work on localising certain components of the vehicles to make the product suitable for local and regional markets.

Local automotive companies, on the other hand, are manufacturing mass transportation vehicles and usually have international alliances for engineering components. Major manufacturers are recently employing in-house designers for product development activities so far usually led by engineers. Some receive external design services from both local and international designers to appeal to local and international markets. This industry takes design consultancy services in a low frequency most likely because,

- The product development strategies of the companies are determined in-house in company headquarters located abroad;

- Product development is highly engineering oriented and requires specialist infrastructure and expertise; and

- This industry tends to work mainly with design consultants with particular experience in this industry.

\section{c. Ceramics Sanitary Ware}

Results indicate that ceramics sanitary ware industry requires design consultancy services in a low frequency. This industry with its sizable production and exporting capacity, is one of the earliest in Turkey where product development activities were carried out within the company, and that employed design professionals such as sculptors and industrial ceramics designers, and later on industrial designers. Nevertheless, it is known to be a conservative sector that has worked with the same designer employees for long periods. Only in recent years, the industry has made use of both local and international design consultancies.

- This industry appears to require novel product ideas particularly when targeting a new market. In this case, this industry seems to prefer design consultants with no particular experience in the area.

- When design consultancy is acquired for novel ideas, in-house designers work on technical detailing and preparation for production. 


\section{MOTIVATIONS FOR AND RESERVATIONS AGAINST DESIGN CONSULTANCY SERVICES OF MANUFACTURING FIRMS}

Based on the survey findings and the authors' experience in the field, motivations for and reservations against getting design consultancy services of the manufacturing firms have been so identified.

\section{Motivations for Acquiring Design Consultancy}

\section{a. Knowledge on Design and Positive Experience with Designers}

The more manufacturing firms are informed on the benefits of industrial design, the more likely they may make use of external design services. These firms may already have in-house designers and be competing in international markets as well.

The initial experiences of a manufacturing firm with design-related activities will have a bearing on determining whether or not the firm will continue to make use of design services. Positive experience leads to the repetition of acquiring design services, whereas negative experience may put off firms from seeking further design services altogether. Therefore, it is important that manufacturing firms should find the most suitable match of design consultancy for their product development needs.

\section{b. Role and Willingness for Cooperation of In-house Designers}

Manufacturing firms conservative in terms of design development due to production processes, may from time to time work with design consultancies for fresh ideas and for developing novel product ranges for a new target market. These firms may also commission worldwide known foreign design consultancies. In such cases, in-house designers assume a supporting role for the consultant and are involved in the solving of technical details and preparation for production.

In manufacturing firms acquired by multinational firms, in-house designers are given the role of localising products. Such firms are willing to make research, and support design related activities such as competitions and design education, but are less likely to work with design consultancies for the development of a product range.

In-house designers may have a major role in encouraging the manufacturing firm to collaborate with design consultancies or to support design related activities in collaboration with other firms or institutions. This is particularly the case when:

- The in-house design department has a significant role in product development and can use initiative in design activities; or

- The in-house design department is mainly consulted for marketing activities and plays a role in research and portfolio development for the firm.

\section{c. Lack of In-House Design Activity}

Manufacturing firms without in-house design activity and with determined branding strategies are more likely to work with design consultancies for the development of a product range. These firms may work with more than one design consultancy at the same time for the development of a series of products. They also tend to work with the same design consultancy for a series of projects. 
Marketing firms without production facilities and in-house design activity may work with design consultancies for the development of their product ranges and form national and international alliances for their production. In such cases, product development activity plays a central role in the alliances and as a strategy products are promoted and marketed with a focus given on design as an added value.

\section{d. Requirement of Expertise Design Consultancy for R\&D}

Manufacturing firms that are highly conservative in terms of R\&D and product development and that are generally engineering oriented may from time to time require services of design consultancies. However these firms tend to prefer working with design consultancies that have experience and expertise in the particular industry and they seem to return to the same consultancy for future projects.

\section{e. Gain of Prestige through Design}

Recently more manufacturing firms apply for design protection of their products, and also apply for national and international awards. Awards won are generally indicated on the products and used in advertisement of the firms.

Manufacturing firms that take design consultancy services use the designers and the outcome of the process in advertisement material such as press releases and TV ads. Firms make large investment on product development and aim to use the outcome in the market for a long term. Therefore, they may prefer not to make such a costly investment on product development frequently. Also, they may choose to work with a different consultancy when the next occasion arises, in order to enrich their portfolio.

\section{Reservations against Acquiring Design Consultancy}

\section{a. In-House Design Activity as Part of a Conservative R\&D Process}

Manufacturing firms where in-house design departments work in collaboration with R\&D and marketing departments, and where these departments seem to be playing a more dominant role in strategic product development, firms seem to be reluctant to work with design consultancies and they keep design activities behind closed doors.

- This is probably due to reasons of confidentiality, particularly about R\&D activities that result in patents.

- This may also be due to specialist skills and infrastructures used in product development, and the relatively longer time allocated for product development activity, which may require that those involved in product development are located within the firm.

- These firms are likely those with more of an engineering tradition, and also those that develop designs with a certain product identity.

Manufacturing firms with in-house design activity and conservative product development process, production facility and clientele, may be reluctant in taking design consultancy services. On the other hand, such firms may from time to time collaborate for external design services with universities and research centres where confidentiality is assured. 


\section{b. Design Services Acquired from other than Local Design Consultancies}

Professional organisations in recent years, hold national and international design competitions open to the participation of students and professionals. Exhibitions and fairs provide opportunities to promote award winning projects to manufacturers. Manufacturing firms may also turn to universities and other research facilities for their product development activities. Through support for design education with projects and research, firms may gain insight into latest developments in their areas of interest.

Manufacturing firms uninformed on the services and benefits of design may take design services from unqualified sources, in-house or external, rather than qualified design professionals. Firms that are not aware of the availability of industrial design services in Turkey may turn to design consultancies abroad for their product development needs. These are particularly research and development firms that have international R\&D alliances.

\section{DISCUSSION}

Financial factors are among reasons why Turkish manufacturing firms do not always prefer to acquire design consultancy services and view design as a luxurious service that raises the cost of production. Firms seem to be reluctant in investing in design and prefer to alter components of products rather than their production line. Although there are financial support mechanisms provided for manufacturers, particularly SMEs for research and development activities, these seem to be mainly used for technological improvements and firms tend to fend for themselves in design and marketing activities, sometimes using unqualified staff or unqualified external services. This may turn out to give a wrong impression of what design could actually have achieved in the right hands. Therefore, firms need to

- be more informed of the services and benefits of industrial design;

- take services from (industrial) designers and not from unqualified persons;

- see the role of industrial designers as leaders in product development; and

- be informed of and ready for the costs of investing in product development.

This points to the necessity of an intermediary professional body in Turkey, that promotes design and design professionals, that is capable of determining the product development needs of firms and matching them with design consultancies.

Another important point to be made is the need for the endowment of a national design policy that will effectively support and promote design profession, thus helping the development of the business of design consultancy among other design oriented issues. More strategic support should be made available, otherwise design consultancy will remain a small business clustered in major industrial regions, with difficulty spreading out to developing industrial regions, and design graduates will incline towards being in-house employees in manufacturing firms. This 
will mean that design as an added value, will not be made available as it should be, in a wider range and in a geographically more spread out region of design oriented production. The rising number of graduates in years to come, though, indicates that government interest towards a national design policy will be inevitable and to good cause.

\section{ACKNOWLEDGMENTS}

We would like to thank the thesis examining committee members Assoc. Prof. Dr. Gülay Hasdoğan, Asst. Dr. Fatma Korkut, Dr. Canan E. Ünlü and Seda Tezsezen for their valuable comments on the thesis from which the survey and its results were presented. We would like to thank the responding design consultancy firms for their contribution to this research.

\section{REFERENCES}

ER, H.A. (2002). Does Design Policy Matter? -The Case of Turkey in a Conceptual Framework, World Design Forum 2002: Design Policy and Global Network, ed. L. Soon-in, Korean Institute of Design Promotion and ICSID, Seoul.

ER, H.A. (1993) The State of Design: Towards an Assessment of the Development of Industrial Design in Turkey, METU Journal of the Faculty of Architecture, 13 (1-2); 31-51.

ER, H.A., KORKUT, F. (1998) Türkiye'de Endüstriyel Tasarım Eğitimi ve Kurumsallaşma: Kronolojik Notlar (Industrial Design Education in Turkey and Institutionalisation: Chronological Notes). Endüstriyel Tasarımcılar Meslek Kuruluşu NESNEL, eds. H.A. Er, F. Korkut, Ö. ER, 11. Boyut Yayın Grubu, İstanbul.

EVYAPAN, N.A.G.Z., KORKUT, F., HASDOĞAN, G. (2006) Implications of Collaboration with Industry for Educational Strategies in Industrial Design: A Case of Graduation Project Course, CLTAD 2006 Proceedings, ed. A. Davies, CLTAD 3rd Int. Conference Enhancing Curricula, 6-7 April 2006, Lisbon. The Center for Learning and Teaching in Art and Design, UK; 137-159.

KORKUT, F., HASDOĞAN, G. (1998) The Profession of Industrial Design in Turkey: The Correspondence between Education and Practice. IDATER 98 Proceedings, eds. J.S. Smith, E.W.L. Norman, IDATER 98: International Conference on Design and Technology Educational Research and Curriculum Development, 24-26 August 1998, Loughborough; 12531.

State Planning Organisation (1989) Altıncı Beş Yıllık Kalkınma Planı (Sixth Five-Year Development Plan), [PDF file] Available at: T.R. Prime Ministry State Planning Organisation http:/ / ekutup.dpt.gov.tr/ plan/plan.asp [Accessed 18 December 2008]. 
Alınd1: 15.10.2010; Son Metin: 12.05.2011

Anahtar Sözcükler: endüstri ürünleri tasarımı; tasarım danışmanlığı; Türk endüstrisi.

\section{TÜRKIYYE'DEKİ TASARIM DANIŞMANLIK FİRMALARININ UZMANLIK ALANLARI, VERILEN HIZMET TÜRLERİ VE MÜŞTERİ FIRMALAR}

Bu makale, Türkiye' deki tasarım danışmanlık firmaları üzerine yürütülen bir araştırmadan kısmi bulgular sunmaktadır. Makale, tasarım danışmanlıklarının uzmanlık alanları, hizmet verdikleri endüstriler, müşteri firmaların ölçekleri ve verilen hizmet türleri üzerine odaklanmaktadır. Araştırmaya 20 tasarım danışmanlık firması katılmıştır. Sonuçlar, tasarım danışmanlık firmalarının Türkiye' deki farklı endüstrilerden küçük, orta ve büyük ölçekli firmalara hizmet verdiklerini göstermektedir. Tasarım danışmanlık firmalarındaki çalışanların mesleki altyapıları firmaların uzmanlık alanları, verdikleri hizmet türleri ve hizmet verdikleri endüstriler üzerinde etkin rol oynamaktadır. Verilen hizmet türleri ayrıca müşteri firmaların ölçeğine göre değişmektedir. Tasarım danışmanlıklarının en sık verdikleri hizmetlerin, küçük ve orta ölçekli firmalar için ürün geliştirme ve pazarlama, büyük ölçekli firmalar için tasarım kavramı (konsept) geliştirme olduğu ortaya çıkmıştır. Yine araştırma göstermektedir ki en fazla tasarım danışmanlık hizmeti alan endüstriler mobilya ve sergi / fuar standları sektörüdür. Öte yandan, Türkiye'deki beyaz eşya, elektrikli ev aletleri, elektronik ürünler, seramik sağlık gereçleri ve otomotiv gibi güçlü endüstriler tasarım danışmanlık hizmetlerini az kullanmaktadır. Bildiri sonuç olarak, endüstrilerin iç dinamiklerini de göz önüne alarak, müşteri firmaların tasarım danışmanlık hizmeti alımı konusundaki motivasyonlarını ve çekincelerini tartışmaktadır.

MÜZEYYEN ALPARSLAN; BSc, M.S.

Graduate of Çankaya University Department of Industrial Engineering (2002). Received her M.S. degree at METU Department of Industrial Design (2007). Worked as quality engineer for A400M Military and Civil Transport Aircraft lighting systems in SELEX Communications for three years; as airworthiness certification engineer in STM Defence Technologies for C-130 Avionics Modernization Program, T-129 ATAK Helicopter Program, Turkish Basic Trainer Aircraft Program and T-38 Trainer Aircraft Avionics Upgrade Program. Currently is the senior quality engineer in Ministry of National Defence Undersecretariat for Defence Industries (SSM) on behalf of STM Defence Technologies. muzeyyensozen@gmail.com

NAZ A.G.Z. BÖREKÇİ; B.I.D., Ph.D.

Graduated from METU Department of Industrial Design (1995), and received Ph.D. in Product Design from Kent Institute of Art and Design/University of Kent at Canterbury (2003).

Currently is Assistant Professor at METU Department of Industrial Design. Her academic interests include design methods and collaboration with industry in industrial design education. nevyapan@metu.edu.tr 